\title{
Trace Metals Concentration Assessment in Urban Particulate Matter in Yenagoa and its Environs
}

\author{
${ }^{1}$ UZOEKWE, SA; ${ }^{2}$ AJAYI, ED \\ ${ }^{I}$ Dept. of Chemical Sciences, Faculty of Science, Federal University, Otuoke, Bayelsa State. \\ ${ }^{2}$ Dept. of Chemistry, Niger-Delta University, Amasoma, Bayelsa State. \\ *Corresponding author's email: uzoekwe_steve@yahoo.com
}

\begin{abstract}
This study was conducted to investigate the distribution and correlation of selected trace elements $(\mathrm{Ca}, \mathrm{Cd}, \mathrm{Co}, \mathrm{Cr}, \mathrm{Cu}, \mathrm{Fe}, \mathrm{Mn}, \mathrm{Ni}, \mathrm{Pb}$, and $\mathrm{Zn}$ ) in Yenagoa, Bayelsa State and its environs. Air particulate matter was collected gravimetrically at five stations (using a high volume portable SKC air check MTXSidekickair sampler (Model: 224-52MTX). The total suspended particulate matter samples were extracted in nitric acid and hydrochloric acid mixture, followed by the quantification of the trace elements by flame Atomic Absorption Spectrophotometric (AAS) method (Model: AA 6600, GBC Avanta PM AAS). The estimated elemental data were then subjected to a set of Multivariate statistical analysis and evaluated for their mutual variations in the urban particles. The concentrations of trace elements $\left(\mu \mathrm{gm}^{-3}\right)$ found in the particulate matter were in the order of $\mathrm{Ca}>\mathrm{Fe}>\mathrm{Zn}>\mathrm{Ni}>\mathrm{Pb}>\mathrm{Mn}>\mathrm{Cu}>\mathrm{Cd}>\mathrm{Co}>\mathrm{Cr}$. On the average, the correlation of the trace elements of the study area shows strong correlations between $\mathrm{Pb}-\mathrm{Ni}, \mathrm{Fe}-\mathrm{Mn}, \mathrm{Co}-\mathrm{Ni}, \mathrm{Zn}-\mathrm{Pb}$, with correlation coefficients of $0.767,0.595,0.508$, and 0.791 respectively. Principal component analysis revealed that major sources of trace metals in ambient air of the study areas were mainly emissions from automobile exhaust, industrial emissions and gas flaring.
\end{abstract}

DOI: https://dx.doi.org/10.4314/jasem.v22i1.25

Copyright: Copyright $\odot 2018$ Uzoekwe and Ajayi. This is an open access article distributed under the Creative Commons Attribution License (CCL), which permits unrestricted use, distribution, and reproduction in any medium, provided the original work is properly cited

Dates: Received 04November 2017; received in revised form 15 December 2017; accepted 21 January 2018

Keywords: Particulate matter, trace elements, enrichment factor, toxic.

Most Nigerian urban cities are confronted with challenges of environmental problems especially atmospheric pollution arising from suspended particulate matter. Concern about air pollution in urban regions is receiving increasing importance worldwide, especially pollution by trace metals (Kabamba et al., 2016). Studies have shown that industrialization and meteorological factors determine the impact of air pollution on a particular location (Mohamade et al., 2016; Pinto et al., 2016 and Gonzalez-Castanedo et al., 2014).Trace elements are released into the atmosphere both from natural and anthropogenic sources namely: resuspended surface dust, combustion of fossil fuels, traffic and industrial activities. One of the most important sources of cadmium, chromium and lead in the urban environment is road traffic (Abiye et al; 2014). High loadings of $\mathrm{Pb}$ and $\mathrm{Ni}$ are due to emissions from vehicles exhaust (Ragosta et. al; 2002; Kim et. al; 2002; Shah et. al; 2006); while Mn and Fe are mainly contributed by earth crust and windblown soil (Quiterio et al; 2004; Sha et al; 2006; Chakraborty and Gupta, 2009).

Yenagoa, located in Bayelsa State is known for oil and gas production with attendant air quality problems. Recently, the state witnessed significant migration from other parts of Nigeria resulting in an increased wave of construction, commercial and industrial activities.
Inorganic component of particulate matters which are mainly trace metals is very important because they are natural constituents of the earth crust and are widely distributed in environmental matrices. At elevated concentrations, all the metals are harmful to living beings including humans (Yasutake and Hiramaya, 1997). The urban population is exposed to the airborne toxic metals that often are well above natural background level (Samura et al; 2003; Zereini et al; 2005; Shridhar et al; 2010). Evident in Niger delta region of Nigeria is the problem of metal particulate air pollution and their role in the oxidation of oxides of sulphur and nitrogen resulting in the formation of acidic aerosols involved in the global acid rain. Many metal ions such as $\mathrm{Mn}^{2+}, \mathrm{Fe}^{3+}, \mathrm{Cu}^{2+}$, $\mathrm{Cr}^{3+}, \mathrm{Al}^{3+}$ and $\mathrm{Pb}^{2+}$ acts like a catalyst in a reaction in which sulphur (IV) acid is oxidized to tetraoxosulphate (IV) acid. Trace elements including $\mathrm{Fe}$, $\mathrm{Va}, \mathrm{Ca}, \mathrm{Pb}, \mathrm{Br}$ and $\mathrm{Cl}$ contribute to the formation of photochemical smog (Ward, 2000).

There are reports of total suspended matters and their trace metal concentrations in urban cities (Okuo and Ndiokwere, 2006; Okuo and Okolo, 2013; Abiye et al; 2014). There is hardly any such report for Yenagoa and its environs despite the importance of this area in oil and gas activities in Nigeria. Thus, the objective of this study is to determine trace metals concentration in ambient air of Yenagoa and its 
environs, major sources of the metals and their enrichment factors.

\section{MATERIALS AND METHOD}

The study area is Yenagoa and its environs in Bayelsa state. It is located in low lying costal area of Niger delta, with coordinates $\mathrm{N} 04^{0} .54^{\mathrm{I}}$ and $\mathrm{E} 06^{0} .15^{\mathrm{I}}$ obtained using a Global Position System unit (GPS Garmin eTrex ${ }^{\circledR}$ version 3.10 ). The vegetation is a typical wetland with two seasons (wet and dry). The temperature throughout the year ranges between $28.6^{\circ} \mathrm{C}$ to $37.5^{\circ} \mathrm{C}$ respectively. The dry season lasts from November to March and the rainy season from April to October. The predominant occupations are fishing and farming but carried out at small scale; settlement is nucleated. The relative humidity ranges between 61 to $90 \%$. The total area of Yenagoa is $706 \mathrm{~km}^{2}$, with a total population of 353,344 (NPC, 2006). The following stations (Berger junction, Onopa by government house, Tombia Roundabout, Gbaran-Ubie, and Ogbogoro Village) were selected for monitoring.

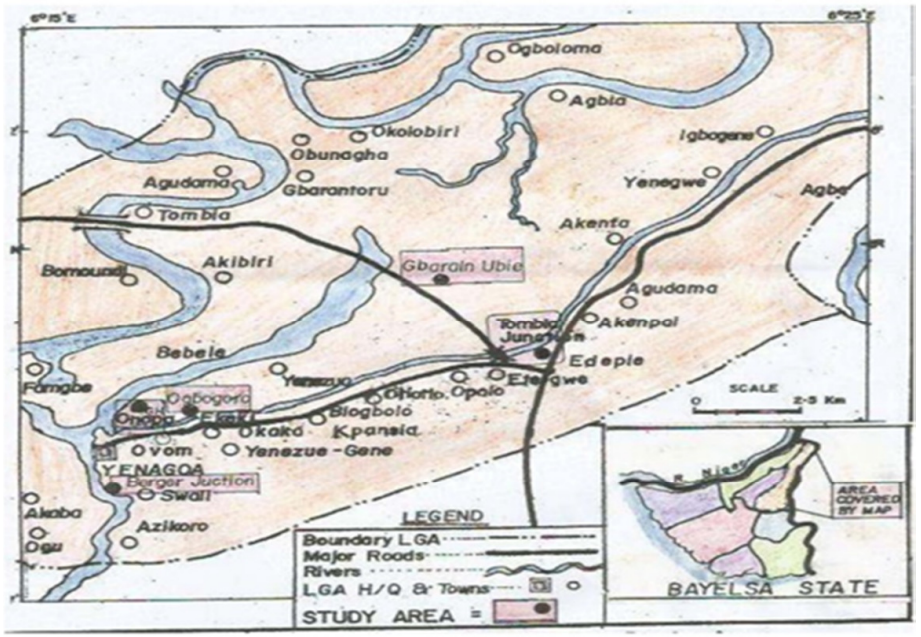

Fig 1: Map of Central Yenagoa displaying sampling stations

\begin{tabular}{|c|c|c|c|c|c|}
\hline S/No & $\begin{array}{l}\text { Sampling } \\
\text { Stations }\end{array}$ & $\begin{array}{l}\text { Sampling } \\
\text { code }\end{array}$ & Coordinates & Activities & $\begin{array}{lr}\text { Distance } & \text { between } \\
\text { location Ref. AQOV Km) }\end{array}$ \\
\hline 1 & $\begin{array}{l}\text { Berger round } \\
\text { about }\end{array}$ & AQBJ & $\begin{array}{l}\mathrm{N} 4^{0} 5322.2^{\prime} \\
\mathrm{E} 6^{0} 1840.1^{\prime}\end{array}$ & $\begin{array}{l}\begin{array}{l}\text { Pulverization of granite, road } \\
\text { construction, } \\
\text { movement, road traffic }\end{array}\end{array}$ & 3.67 \\
\hline 2 & $\begin{array}{l}\text { Onopa by } \\
\text { Govt House }\end{array}$ & AQON & $\begin{array}{l}\mathrm{N} 4^{0} 5623.2 \\
\mathrm{E} 6^{0} 1644.1\end{array}$ & $\begin{array}{l}\text { Vehicular movement, road traffic, } \\
\text { road construction, residential } \\
\text { activities }\end{array}$ & 4.65 \\
\hline 3 & $\begin{array}{l}\text { Tombia } \\
\text { Roundabout }\end{array}$ & AQTR & $\begin{array}{l}\mathrm{N} 4^{0} 5000.8^{\prime} \\
\mathrm{E} 6^{0} 1541.2\end{array}$ & $\begin{array}{l}\text { High vehicular movement, road } \\
\text { traffic, commercial activities, } \\
\text { open dump site, residential } \\
\text { activities, abbatoire, open burning } \\
\text { of animal parts }\end{array}$ & 9.81 \\
\hline 4 & Gbaran-Ubie & AQGU & $\mathrm{N} 4^{0} 4822.4^{\prime}$ & $\begin{array}{l}\text { Gas flaring, vehicular movement, } \\
\text { residential activities }\end{array}$ & 13.58 \\
\hline 5 & $\begin{array}{l}\text { Ogbogoro } \\
\text { village }\end{array}$ & AQOV & $\begin{array}{l}\mathrm{E}^{0} 5440.0^{\prime} \\
\mathrm{N} 4^{0} 5408.6^{\prime} \\
\mathrm{E} 6^{0} 1450.8\end{array}$ & $\begin{array}{l}\text { Road construction, few vehicular } \\
\text { movements, low residential } \\
\text { activities }\end{array}$ & 0 \\
\hline
\end{tabular}

Sampling Technique:The study was carried out from the month of July 2013 to January 2014. Samples were collected for a period of 7 months to ensure that both wet and dry seasons were covered. Particulate matter samples were collected using a SKC air check MTX Sidekick sampling pump, (224-52MTX Model) by filtration through whatman membrane filters of $25 \mathrm{~mm}$ with pore size of $3.0 \mu \mathrm{m}$ for 8 hours (Ogunsola et al., 1994, USEPA, 1999). The high volume sampler operates at a flow rate of $2.2 \mathrm{~L} \mathrm{~min}{ }^{-1}$ A total of $1056 \mathrm{~L}$ of air was pumped through a filter for $8 \mathrm{hrs}$ on each occasion. This sampling unit consists of a filter holder manifold connected to the sampling pump by a Teflon tube. Airborne particulate matter was collected on whatman filter paper. The sampler was installed on top of a building approximately 4.0$6.0 \mathrm{~m}$ high above the ground level and well cleared from other buildings around. Filter papers were 
equilibrated in a desiccator for 24hours and weighed before and after sampling. Weighing balance meter AE200 was used. Each filter was weighed three times to obtain a constant and accurate weight before recording. Blank filters were also subjected to same condition and weight recorded. All filter handling was done using vinyl gloves to avoid contamination.

Collection of Sample:Samples were collected from five different locations for seven months. The particulate matter was obtained by pumping air through the filter paper for 8 hours (Ogunsola et al., 1994, UNEP/WHO, 1994).After sampling, the loaded filter was again desiccated and reweighed to determine the final weight.

Sample Preparation and Instrument Analysis:For the estimation of selected elements, the loaded filter paper was extracted by a mixture of $20 \mathrm{ml}$ of high purity $65 \%$ nitric acid and of $37 \%$ hydrochloric acid (USEPA, 1999). This solution was boiled gently until it approached near dryness to boil off the excess acid and cooled to room temperature and filled to $50 \mathrm{ml}$ mark. This was then analyzed by Atomic Absorption Spectrometer (AAS) (Model AA 6600, GBC Avanta PM)

Data Analysis: Basic statistical parameters, multivariate analysis comprising principal component analysis (PCA), correlation matrix (CR) and cluster analysis (CA) were performed on the dataset using SPSS software version 21.0.

Enrichment Factor:Enrichment factors(EFs) was calculated using Calciumas reference element to find out the anthropogenic origin of atmospheric trace elements (Arditsoglou and Samara; et al., 2005; Sha and Shahoeni 2008; Shridhar et al., 2010). Usually, $\mathrm{Na}, \mathrm{K}, \mathrm{Al}, \mathrm{Mg}, \mathrm{Ca}, \mathrm{Mn}$ and $\mathrm{Fe}$ are used as the reference (Munir et al., 2013a, b). In this analysis, calcium $(\mathrm{Ca})$ was used as the reference element because it correlated well, the enrichment factor is calculated using the equation:

$$
E F_{X}=\frac{\left(\frac{X}{\mathrm{Ca}}\right) \text { sample }}{\left(\frac{\mathrm{X}}{\mathrm{Ca}}\right) \mathrm{crust}}
$$

Where $\mathrm{EF}(\mathrm{x})$ is the ratio of element to reference material, (X/Ca) Sample and (X/Ca) Crust refer to the mean concentrations of the target element and $\mathrm{Ca}$ in atmospheric particulate matter and in continental crust, respectively. The EFs are calculated on the basis of earth crust mean abundance of the metals (Wedepohl, 1995).

\section{RESULTS AND DISCUSSION}

Trace Metal Occurrence and Distribution: The mean concentration for different trace metals at various locations (AQBJ, AQON, AQTR, AQGU and AQOV) are shown in (Table 2). On the average, the highest mean concentration (approximated) was found for $\mathrm{Ca}$ at $216.76 \times 10^{-2} \mu \mathrm{gm}^{-3}$, followed by $\mathrm{Fe}$ $\left(65.39 \times 10^{-2} \mu \mathrm{gm}^{-3}\right), \mathrm{Zn}\left(5.80 \times 10^{-2} \mu \mathrm{gm}^{-3}\right), \mathrm{Ni}(1.26 \mathrm{x}$ $\left.10^{-2} \mu \mathrm{gm}^{-3}\right), \mathrm{Pb}\left(0.53 \times 10^{-2} \mu \mathrm{gm}^{-3}\right), \mathrm{Mn}\left(0.44 \times 10^{-}\right.$ $\left.{ }^{2} \mu \mathrm{gm}^{-3}\right), \mathrm{Cu}\left(0.43 \times 10^{-2} \mu \mathrm{gm}^{-3}\right) \mathrm{Cd}\left(0.17 \times 10^{-2} \mu \mathrm{gm}^{-3}\right)$, Co $\left(0.16 \times 10^{-2} \mu \mathrm{gm}^{-3}\right)$, Cr $\left(0.08 \times 10^{-2} \mu \mathrm{gm}^{-3}\right)$. On the average, the decreasing elemental concentration trend was: $\mathrm{Ca}>\mathrm{Fe}>\mathrm{Zn}>\mathrm{Ni}>\mathrm{Pb}>\mathrm{Cu}>\mathrm{Mn}>\mathrm{Cu}>\mathrm{Cd}>\mathrm{Co}>\mathrm{Cr}$. The correlation study between the locations presented in tables 3-7 showed that all locations correlated well, except Gbaran-Ubie and Ogbogoro village which is not unconnected with the marked differences in the activities in these two locations and their distant apart relative to others. On the average, the correlation of the trace elements of the study area shows strong correlations between $\mathrm{Pb}-\mathrm{Ni}$, Fe-Mn, Co-Ni, Zn-Pb, with correlation coefficients of $0.767,0.595,0.508$ and 0.791 respectively.

Table 2. Statistical summary of trace elements level $\left(\mu \mathrm{gm}-{ }^{3} \times 10^{-2}\right)$ in air borne particulate matter

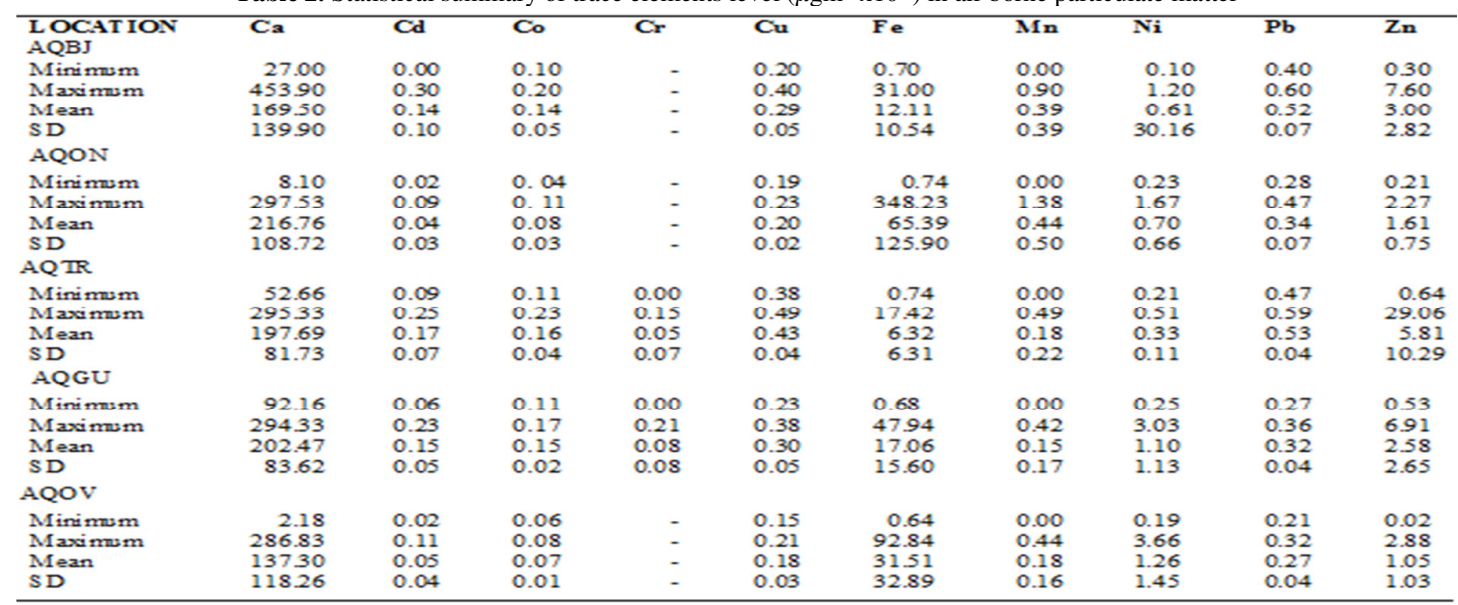


Source Apportionment: To probe the origin of trace metals in Yenagoa and its environs in this study, source apportionment has been performed by applying principal factor analysis (PCA) and computation of enrichment factor. PCA explains the quantitative information of those metals and their corresponding sources (Park and Kim, 2005). The data acquired at the five sampling locations were used to conduct PCA analysis and the result is presented in table 8. Three factors were identified as those contributing to the measured values in each of the locations. At AQBJ (Berger Junction), , $\mathrm{Zn}, \mathrm{Cu}, \mathrm{Ca}$, $\mathrm{Cd}, \mathrm{Pb}$, and $\mathrm{Co}$ loaded positively with component 1 and $49.21 \%$ variance, $\mathrm{Cd}, \mathrm{Mn}$ and $\mathrm{Ni}$ loaded positively with component 2 and $21.93 \%$ variance, while $\mathrm{Pb}, \mathrm{Co}$ and $\mathrm{Ni}$ loaded positively with component 3 and $15.25 \%$ variance. At AQON (Onopa) $\mathrm{Zn}, \mathrm{Cu}, \mathrm{Ca}, \mathrm{Cd}, \mathrm{Mn}$ and $\mathrm{Pb}$ loaded positively with component 1 and $52.79 \%$ variance; only Co loaded with component 2 (19.1\% variance) while $\mathrm{Fe}$ and $\mathrm{Mn}$ loaded positively with component 3 and $13.42 \%$ variance.

Table 3. Spearman correlation for selected trace elements in air borne particulate matter at AQBJ

\begin{tabular}{c|rrrrrrrrr}
\hline Metals & \multicolumn{1}{c}{$\mathrm{Fe}$} & $\mathrm{Zn}$ & $\mathrm{Cu}$ & $\mathrm{Ca}$ & $\mathrm{Cd}$ & $\mathrm{Mn}$ & $\mathrm{Pb}$ & $\mathrm{Co}$ & $\mathrm{Ni}$ \\
\hline $\mathrm{Fe}$ & 1.000 & & & & & & & & \\
$\mathrm{Zn}$ & .276 & 1.000 & & & & & & & \\
$\mathrm{Cu}$ & .076 & .823 & 1.000 & & & & & & \\
$\mathrm{Ca}$ & .130 & .620 & .800 & 1.000 & & & & & \\
$\mathrm{Cd}$ & -.054 & .371 & .462 & .682 & 1.000 & & & & \\
$\mathrm{Mn}$ & -.213 & .029 & .449 & .713 & .779 & 1.000 & & & \\
$\mathrm{~Pb}$ & .011 & .791 & .670 & .422 & .632 & .206 & 1.000 & & \\
$\mathrm{Co}$ & -.092 & .759 & .765 & .258 & .150 & -.038 & .761 & 1.000 & \\
$\mathrm{Ni}$ & -.274 & -.589 & -.542 & -.549 & .140 & .085 & .009 & -.283 & 1.000 \\
\hline
\end{tabular}

Table 4. Spearman correlation coefficient for selected trace elements in air particulate matter at AQON

\begin{tabular}{llllllllll}
\hline Metals & $\mathrm{Fe}$ & \multicolumn{1}{c}{$\mathrm{Zn}$} & $\mathrm{Cu}$ & $\mathrm{Ca}$ & $\mathrm{Cd}$ & $\mathrm{Mn}$ & $\mathrm{Pb}$ & $\mathrm{Co}$ & $\mathrm{Ni}$ \\
\hline $\mathrm{Fe}$ & 1.000 & & & & & & & & \\
$\mathrm{Zn}$ & -.011 & 1.000 & & & & & & & \\
$\mathrm{Cu}$ & .207 & .471 & 1.000 & & & & & & \\
$\mathrm{Ca}$ & .085 & .988 & .439 & 1.000 & & & & & \\
$\mathrm{Cd}$ & -.063 & .559 & .928 & .527 & 1.000 & & & & \\
$\mathrm{Mn}$ & -.240 & .567 & .514 & .482 & .576 & 1.000 & & & \\
$\mathrm{~Pb}$ & -.044 & .536 & .603 & .563 & .731 & -.014 & 1.000 & & \\
$\mathrm{Co}$ & .107 & .632 & .000 & .677 & .047 & -.089 & .390 & 1.000 & \\
$\mathrm{Ni}$ & -.337 & .547 & .774 & .498 & .905 & .390 & .847 & .161 & 1.000 \\
\hline
\end{tabular}

At AQTR (Tombia roundabout), $\mathrm{Cu}, \mathrm{Cr}, \mathrm{Ca}, \mathrm{Cd}, \mathrm{Pb}$, $\mathrm{Ni}$ loaded positively with component 1 while $\mathrm{Mn}$ loaded negatively with \% variance of $55.51 \%$. Fe, $\mathrm{Zn}$ and $\mathrm{Mn}$ loaded positively with component 2 . At AQGU (Gbaran-Ubie), Ca, Cr, Cd, Pb, Co, Ni loaded positively with component 1 while $\mathrm{Zn}$ loaded negatively with $54.61 \%$ variance. $\mathrm{Cu}$ loaded positively and Mn negatively with component 2 having $20.26 \%$ variance while only Fe loaded positively with component 3 with $12.99 \%$ variance.
At AQOV (Ogbogoro Village), $\mathrm{Fe}, \mathrm{Cu}, \mathrm{Cd}, \mathrm{Pb}$, and $\mathrm{Ni}$ loaded positively with component 1 and $46.74 \%$ variance. $\mathrm{Zn}, \mathrm{Ca}, \mathrm{Mn}$, and Co loaded positively with component 2 and $31.19 \%$ variance while Co loaded only with component 3 and $14.80 \%$ variance.

Table 5. Spearman correlation coefficient for selected trace elements in air particulate matter at AQTR

\begin{tabular}{l|rrrrrrrrrr}
\hline Metals & \multicolumn{1}{c}{$\mathrm{Fe}$} & $\mathrm{Cr}$ & $\mathrm{Zn}$ & $\mathrm{Cu}$ & $\mathrm{Ca}$ & $\mathrm{Cd}$ & $\mathrm{Mn}$ & $\mathrm{Pb}$ & $\mathrm{Co}$ & $\mathrm{Ni}$ \\
\hline $\mathrm{Fe}$ & 1.000 & & & & & & & & & \\
$\mathrm{Cr}$ &. .442 & 1.000 & & & & & & & & \\
$\mathrm{Zn}$ & .432 & -.259 & 1.000 & & & & & & & \\
$\mathrm{Cu}$ & -.302 & .606 & -.360 & 1.000 & & & & & & \\
$\mathrm{Ca}$ & .040 & .779 & -.240 & .696 & 1.000 & & & & & \\
$\mathrm{Cd}$ &. .242 & .812 & .213 & .691 & .689 & 1.000 & & & & \\
$\mathrm{Mn}$ & .495 & -.662 & .526 & -.323 & -.260 & -.331 & 1.000 & & & \\
$\mathrm{~Pb}$ & -.251 & .680 & .097 & .795 & .711 & .903 & -.186 & 1.000 & & \\
$\mathrm{Co}$ &. .653 & .858 & -.283 & .629 & .621 & .715 & -.397 & .616 & 1.000 & \\
$\mathrm{Ni}$ & .287 & .369 & -.065 & .908 & .426 & .665 & -.076 & .767 & .508 & 1.000 \\
\hline
\end{tabular}

Table 6. Spearman correlation coefficient for selected trace element in air borne particulate matter at AQGU

\begin{tabular}{l|llllllllll}
\hline & \multicolumn{1}{l}{$\begin{array}{l}\text { Fe } \\
\text { Cr }\end{array}$} & \multicolumn{1}{c}{$\mathrm{Zn}$} & $\mathrm{Cu}$ & $\mathrm{Ca}$ & $\mathrm{Cd}$ & $\mathrm{Mn}$ & $\mathrm{Pb}$ & $\mathrm{Co}$ & $\mathrm{Ni}$ \\
$\mathrm{Fe}$ & 1.000 & & & & & & & & & \\
$\mathrm{Cr}$ & -.306 & 1.000 & & & & & & & & \\
$\mathrm{Zn}$ & .230 & -.573 & 1.000 & & & & & & & \\
$\mathrm{Cu}$ & -.012 & .276 & -.069 & 1.000 & & & & & & \\
$\mathrm{Ca}$ & -.354 & .853 & -.619 & .229 & 1.000 & & & & & \\
$\mathrm{Cd}$ & .154 & .739 & -.741 & .448 & .756 & 1.000 & & & & \\
$\mathrm{Mn}$ & -.045 & .041 & -.398 & -.713 & .171 & .092 & 1.000 & & & \\
$\mathrm{~Pb}$ & -.143 & .891 & -.745 & .377 & .916 & .918 & .034 & 1.000 & & \\
$\mathrm{Co}$ & .153 & .664 & -.726 & .073 & .397 & .739 & .330 & .636 & 1.000 & \\
$\mathrm{Ni}$ & -.087 & .852 & -.387 & .446 & .784 & .709 & -.336 & .872 & .409 & 1.000 \\
\hline
\end{tabular}

Table.7. Spearman correlation coefficient for selected trace element in air borne particulate matter at AQOV

\begin{tabular}{r|lllllllll}
\hline Metals & $\mathrm{Fe}$ & $\mathrm{Zn}$ & $\mathrm{Cu}$ & $\mathrm{Ca}$ & $\mathrm{Cd}$ & $\mathrm{Mn}$ & $\mathrm{Pb}$ & $\mathrm{Co}$ & $\mathrm{Ni}$ \\
\hline $\mathrm{Fe}$ & 1.000 & & & & & & & & \\
$\mathrm{Zn}$ & .418 & 1.000 & & & & & & & \\
$\mathrm{Cu}$ & .763 & .044 & 1.000 & & & & & & \\
$\mathrm{Ca}$ & -.016 & .658 & -.600 & 1.000 & & & & & \\
$\mathrm{Cd}$ & .582 & -.269 & .817 & -.561 & 1.000 & & & & \\
$\mathrm{Mn}$ & .101 & .600 & -.404 & .864 & -.239 & 1.000 & & & \\
$\mathrm{~Pb}$ & .840 & .041 & .654 & -.112 & .757 & .016 & 1.000 & & \\
$\mathrm{Co}$ & .202 & .143 & .115 & .220 & .486 & .645 & .307 & 1.000 & \\
$\mathrm{Ni}$ & .898 & .326 & .817 & -.163 & .565 & -.132 & .689 & .020 & 1.000 \\
\hline
\end{tabular}

On the average, $\mathrm{Pb}, \mathrm{Cu}, \mathrm{Cd}, \mathrm{Zn}$, and $\mathrm{Ca}$ loaded with PC1 positively: these elements are believed to be originated from automobile and industrial emission (Lee and Hieu, 2011; Okuo et al., 2006). PC2 had higher principal component loading for $\mathrm{Fe}$ and $\mathrm{Mn}$, along with considerable contribution from Co. This revealed close association of $\mathrm{Fe}$ and $\mathrm{Mn}$ in TSP in Urban atmosphere, mainly contributed by earth crust and wind-blown soil from road dust resuspension (Ragosta et al., 2002; Quiterio et al., 2004; Shah et 
al., 2006). On the other hand, Co, and considerable contribution from $\mathrm{Ni}$ and $\mathrm{Pb}$ loaded with $\mathrm{PC} 3$; these are believed to originate from residual oil combustion (Khodeir et al., 2012). This is in support of studies carried out by Okuo et al., (2006) and Bhawna et al., (2012). Total suspended particulates matters for each location correlated well, an indicator that similar factors are responsible for pollution in the locations. However, Gbaran-Ubie and Ogbogoro village showed a slight variation and this is not unconnected with the marked differences in the nature of activities and their distance apart relative to others. Three components extracted and identified as the major sources of pollution in Yenagoa and its environs are: industrial emissions, emissions from automobile exhaust and gas flaring.

A more comprehensive understanding of the origin of trace elements in atmospheric particulate matter demands developing relationships between airborne TSP and soil, through the Enrichment Factors (EFs). Estimation of EFs is a measure to find out the anthropogenic origin of atmospheric trace elements. The results of EFs can provide useful evidence for the human intrusion of the elements in TSP by using measured element concentrations in particulates (Arditsoglou and Samara, 2005; Zereini et al., 2005; Shah and Shaheen, 2008; Shridhar et al., 2010). The $\mathrm{EF}$ value close to unity suggests that the element is dominantly contributed by natural soil dust or the contribution of anthropogenic sources is not significant. The values much higher than 1 may imply sources other than crustal dust; these sources include human activities (e.g., combustion, automobile and industrial emissions, agricultural activities etc.) and other processes (e.g. forest fires, volcanoes, sea salt). EFs are usually taken as double ratios of the target element and a reference element in aerosols and earth crust. The reference element must be one that is overwhelmingly derived from a natural source.

Enrichment factor was calculated and the results present in table 9 for these trace elements. The average values for iron, copper, cobalt, nickel and zinc are $2.41,1.99,1.14,4.53$ and 5.23 respectively. This shows that they are less enriched $(\mathrm{EF}<10)$, while the values for lead, cadmium, manganese, are: 105.87, 63.54 and 70.39 respectively. Lead was highly enriched (EF>100), while cadmium and manganese are moderately enriched (EF between 10 and 100) (Munir et al., 2013a,b). If EF approaches unity, crustal is the predominant source. Lead has the highest $\mathrm{EF}$, followed by manganese and cadmium which is in agreement with Okuo et al., 2011, and Okuo et al., 2006. Road traffic involves the emission of a wide range of trace elements that includes $\mathrm{Pb}$, $\mathrm{Cu}, \mathrm{Zn}$ and $\mathrm{Cd}$ (Gunawardena et al., 2012); Ni and V are tracers for oil combustion (Peltier et al., 2009; Peltier and Lippmann, 2010). Therefore, the EF calculated in this study tend to suggests strongly that combustion sources such as gas flaring and vehicular movement influence trace metal pollution of ambient air of Yenagoa and its environ.

Table 8.Principal component loadings of selected elements in the air borne particulate matter

\begin{tabular}{|c|c|c|c|c|c|c|c|c|c|c|c|c|c|c|}
\hline & \multicolumn{3}{|c|}{ AOBJ } & \multicolumn{3}{|c|}{$\mathrm{AOON}$} & \multicolumn{2}{|r|}{ AOTR } & \multicolumn{3}{|c|}{ AOGU } & \multicolumn{3}{|r|}{ AOOV } \\
\hline & PC1 & PC2 & PC3 & PC1 & PC2 & PC3 & PC1 & PC2 & PC1 & PC2 & PC3 & PC1 & PC2 & PC3 \\
\hline Eigen value & 4.43 & 1.97 & 1.37 & 4.75 & 1.72 & 1.21 & 5.55 & 1.91 & 5.46 & 2.03 & 1.299 & 4.21 & 2.81 & 1.33 \\
\hline$\%$ Total variance & 49.21 & 21.93 & 15.25 & 52.79 & 19.10 & 71.89 & 55.50 & 19.08 & 54.61 & 20.26 & 12.99 & 46.74 & 31.19 & 14.79 \\
\hline \%Cumulative va riance & 49.21 & 71.13 & 86.38 & 52.79 & 71.89 & 85.30 & 55.50 & 74.58 & 54.61 & 74.87 & 87.86 & 46.74 & 7794 & 92.7 .5 \\
\hline $\mathrm{Ca}$ & 0.84 & & & 0.83 & & & 0.78 & & 0.89 & & & & 0.84 & \\
\hline$c d$ & 0.66 & 0.66 & & 0.90 & 0.84 & & 0.88 & & 0.92 & & & 0.88 & & \\
\hline Co & & & 0.53 & & & & 0.86 & & 0.99 & & & & 0.54 & 0.78 \\
\hline $\mathrm{Cr}$ & 0.95 & & & & & & & & 0.92 & & & & & \\
\hline $\mathrm{Cu}$ & & & & 0.81 & & & 0.88 & & & 0.80 & & 0.95 & & \\
\hline $\mathrm{Fe}$ & & & & & & 0.64 & & 0.60 & & & 0.94 & 0.86 & & \\
\hline $\begin{array}{l}\mathrm{Mn} \\
\mathrm{Ni}\end{array}$ & & $\begin{array}{l}0.81 \\
0.56\end{array}$ & 0.55 & $\begin{array}{l}0.57 \\
0.88\end{array}$ & & 0.61 & $\begin{array}{l}0.51 \\
0.73\end{array}$ & 0.65 & 0.84 & 0.97 & & 0.86 & 0.92 & \\
\hline $\mathbf{P b}$ & 0.80 & & 0.51 & & & & 0.87 & & 0.99 & & & 0.85 & & \\
\hline $\mathrm{Zn}$ & 0.89 & & & & & & & 0.78 & 0.77 & & & & 0.81 & \\
\hline \multicolumn{2}{|c|}{ ELEMENT } & \multicolumn{2}{|c|}{ AQBJ } & \multicolumn{2}{|c|}{ AQON } & \multicolumn{2}{|r|}{ AQTR } & \multicolumn{2}{|r|}{ AQGU } & \multicolumn{2}{|r|}{ AQOV } & \multicolumn{3}{|c|}{ AVERAGE } \\
\hline \multicolumn{2}{|l|}{ Cadmium } & \multicolumn{2}{|c|}{86.95} & \multicolumn{2}{|c|}{19.70} & \multicolumn{2}{|r|}{88.68} & \multicolumn{2}{|r|}{78.59} & \multicolumn{2}{|r|}{40.78} & \multicolumn{3}{|c|}{63.54} \\
\hline \multicolumn{2}{|l|}{ Cobalt } & \multicolumn{2}{|c|}{1.40} & \multicolumn{2}{|c|}{0.65} & \multicolumn{2}{|r|}{1.43} & \multicolumn{2}{|r|}{1.30} & \multicolumn{2}{|r|}{0.91} & \multicolumn{3}{|c|}{1.14} \\
\hline \multicolumn{2}{|l|}{ Copper } & \multicolumn{2}{|c|}{2.24} & \multicolumn{2}{|c|}{1.22} & & 2.83 & & 1.93 & & 1.74 & & 1.99 & \\
\hline Iron & & 0.8 & 85 & & .69 & & 2.18 & & 5.74 & & 1.56 & & 2.41 & \\
\hline Manganes & & 93. & .09 & & .77 & & 37.61 & & 87.48 & & 52.02 & & 70.39 & \\
\hline Nickel & & 3.8 & 89 & & .43 & & 1.77 & & 3.68 & & 9.86 & & 4.53 & \\
\hline Lead & & 148 & .68 & & 7.42 & & 130.07 & & 76.76 & & 96.43 & & 105.87 & \\
\hline Zinc & & 6. & 15 & & 60 & & 10.27 & & 4.46 & & 2.67 & & 5.23 & \\
\hline Calcium & & 1. & 00 & & .00 & & 1.00 & & 1.00 & & 1.00 & & 1.00 & \\
\hline
\end{tabular}


Conclusion: In conclusion, present study showed that among the selected trace metals $\mathrm{Pb}$ and $\mathrm{Cd}$ have high enrichment factor and this is considered serious as these are hazardous to human health. Correlation study along with multivariate PCA evidenced significant anthropogenic contribution of the measured pollutants in the urban atmosphere of Yenagoa. Major atmospheric pollution sources were automobile emissions, industrial emissions, and gas flaring. Lead was highly enriched, while Cadmium and Manganese are moderately enriched. This shows impact of anthropogenic activities in the local atmosphere, which may have adverse health effects on the city dwellers.

\section{REFERENCES}

Abiye OE, Obioh IB, Ezeh GC, Alfa A, Ojo EO, Ganiyu AK (2014). Receptor modeling of atmospheric aerosols in Federal Capital Territory (FCT), Nigeria. Ife J Sci. 16(1):107-119

Arditsoglou, A; Samara, C (2005). Levels of total suspended particulate matter and major trace elements in Kosovo: A source identification and apportionment study. Chemosphere 59:669-678.

Bhawna, D; Asim, KP; Gurdeep, S (2012). Trace metal composition of airborne particulate matter in the coal mining and non-mining areas of Dhanbad Region, Jharkhand, India, Atmo. Pollut. Res. 3 (2):238-246.

Chakraborty, A; Gupta, T (2009). Chemical characterization of submicron aerosol in Kanpur region: a source apportionment study. International Journal of Civil and Environmental Engineering 1:87-90

Gonzalez-Castanedo, Y; Moreno, T; FernandezCamacho, R; Sanchez de la campa, AM; Alastucy, A; Querol, X; Rosa, J de la (2014). Size distribution and chemical composition of particulate matter stack emissions in and around a copper smelter, Atmos. Environ. 98:271-282.

Gunawardena, J; Egodawatta, P; Myoko, GA; Goonetilleke, A (2012). Role of traffic in atmospheric accumulation of heavy metals and polycydic aromatic hydrocarbons, Atmos. Environ. 54:502-510.

Ikamaise, VC; Akpan, IO; Essiet, AA; Uwah, IE (2013). Concentrations and source apportionment of total suspended particulate matters in Calabar Air Basin, International Journal of Development and Sustainability 2(2):1203-1213.
Kabamba, M; Basosila, N; Malaji, C; Mata, H; Tuakuila, J (2016). Toxic Heavy Metals in Ambient Air of Kinshasha, Democratic Republic of Congo. Journal of Chemistry3(2):1000178.

Khodeir, M, Shamy, M; Alghamdi M; Sun, H; Costa, M, Chen, LC, Maciejczyk P (2012) Source apportionment and elemental composition of $\mathrm{PM}_{2.5}$ and $\mathrm{PM}_{10}$ in Jeddah City, Saudi Arabia, AtmosPollut. Res 3:331-340

Kim, KH; Lee, JH; Jang, MS (2002). Metals in airborne particulate matter from the first and second industrial complex area of Taejon City, Korea. Environmental Pollution 118:41-51.

Lee BK, Hieu NT (2011) Seasonal variation and sources of heavly metals in atmospheric aerosols in a residential area of Ulsan, Korea. Aerosol Air Qual Res 11:679-688

Mohamed, RMSR; Nizam, NMS; Al-Gheethi, AA; lajis, A; Kassim, AHM. (2016). Particulate Matter levels in Ambient Air Adjacent to Industrial Area, IOP conference series: Materials Science and Engineering $136 \quad 012056$ http://iopscience.iop.org/1757-899X/136/1/

Munir, S; Habeebullah, TM; Seroji, AR; Gabr, SS; Mohammed, AMF; Morsy, EA (2013a). Quantifying temporal trends of atmospheric pollutants in Makkah (1997-2012). Atmos. Environ. 77: 647-655.

Munir, S; Habeebullah, TM; Seroji, AR; Morsy, EA; Mohammed, AMF; Abu Saud, W; Abdou, AEA; Awad, AH (2013b). Modeling particulate matter concentrations in Makkah, applying a statistical modeling approach. Aerosol Air Qual. Res. 13: 901-910.

NPC, (2006). National Population Census. Federal Republic of Nigeria Official Gazette, 96(2)

Ogunsola OJ; Oluwole AF; Asubiojo OI; Olaniyi HB; Keredolu FA; Akanle OA; Spyrou, NM; Ward, NI; Ruck, W (1994). Traffic pollution: Preliminary elemental characterization of road side dust in Lagos, Nigeria. Sci. Total Environ. 146 / 147: 175-184.

Okuo, JM; Okolo PO (2011). Levels of As, Pb, Cd and $\mathrm{Fe}$ in suspended particulate matter (SPM) in Ambient air of Artisan workshops in Benin City, Nigeria, BayeroJournal of Pure and Applied Sciences 4(2) : 97-99. 
Okuo, J.M; Ndiokwere, CL (2005). Elemental concentration of total suspended particulate matters in Relation to Air pollution in Niger Delta of Nigeria: A case study of Warri, Trends in Applied Sciences Research (1): 91-96.

Park, SS; Kim, YJ (2005). Source contributions to fine particulate matter in an urban atmosphereChemosphere 59:217-226.

Peltier, RE; Lippmann, M (2010). Residual oil combustion: 2 Distributions of airborne nickel and vanadian with New York City. J.Expos. Sci. Environ. Epidemiol. 20:342-350.

Peltier, RE; HSU, SI; Lau, R; Lippmann, M (2009). Residual oil combustion: A major source of airborne nickel in New York City, J. Expos. Sci. Environ. Epidemio. 19:603-612.

Pinto, E; Soares, C; Couto, CM; Almeida, A (2015). Trace Elements in Ambient Air at Porto Metropolitan Area-checking compliance with new European Union (EU). Air Quality standards, Journal of Toxicology and Environmental Health PartA: Current Issues, 78:848-859.

Quiterio, SL; da Silva, CRS; Arbilla, G; Escaleira, V (2004). Metals in airborne particulate matter in the industrial district of Santa Cruz, Rio de Janeiro, in an annual period. Atmosphere Environment 38:321-331.

Ragosta, M; Caggino, R; D’Emilio, M; Macchiato, M (2002). Source origin and parameters influencing levels of heavy metals in TSP, in an industrial background area of southern Italy. Atmospheric Environment 36:3071-3087.

Rizzio, E; Giaveri, G; Arginelli, D; Gini profumo, A; Gallorini, M (1999).Trace elements total content and particle sizes distribution in the air particulate matter of a rural-residential area in north Italy investigated by instrumental neutron activation analysis. Science of the Total Environment 226:47-56.

Samura, A; Al-Agha, O; Tuncel, SG (2003). Study of trace and heavy metals in rural and urban aerosols of Uludag and Bursa (Turkey). Water, Air and Soil Pollution: Focus 3:111-129.

Shah, MH; Shaheen, N (2000). Annual and seasonal variations of trace metals in atmospheric suspended particulate matter in Islamabad, Pakistan. Water Air and Soil Pollution 190:1325 .

Shridhar, V; Khillare, PS; Agarwal, T; Ray, S (2010). Metallic species in ambient particulate matter at rural and urban location of Delhi, Journal of Hazardous Materials 175:600-607.

UNEP/WHO (1999). Health and Environmental Linkages Initiatives (HELI), Epidemiology, 10(5):573-584.

United States Environmental Protection Agency (USEPA, 1999). Determination of metals in ambient particulate matter using inductivity coupled plasma (ICP) Spectroscopy. Compendium method 10-3.4. Centre for Environmental Research Information Office of Research and Development, USEPA, Cincinnati; OH 45268.

Ward, NI (2000). Trace elements, In: Environmental Analytical Chemistry (Ed: P.W. Field and P.J Haines, $2^{\text {nd }}$ Edition) Blackwell science Ltd, Osney Mead, Oxford Ox2 OEL. www.blackwellscience.com (2000).

Wedepohl, $\mathrm{KH}$

(1995). GeochimicaetCosmochimicaActa, 59:1217-1232.

Yasutake, A; Hirayama, K (1997). Animal models: In Handbook of human toxicology (Ed: E.J. Massaro). CRC press, Boca Raton, New York.

Zereini, F; Alt, F; Messerschmidt, J; Wiseman, C; Feldmann, I; Von Bohlen, A; Muller, J., Liebi, K; Puttmann, W. (2005). Concentration and distribution of heavy metals in urban airborne particulate matter in Frankfurt am Main, Germany, Environmental Science and Technology 39:2983-2989. 